\title{
Investigating volcanic hazard in Cape Verde Islands through geophysical monitoring: network description and first results
}

\author{
B. Faria ${ }^{1}$ and J. F. B. D. Fonseca ${ }^{2}$ \\ ${ }^{1}$ Instituto Nacional de Meteorologia e Geofísica, Delegação de S. Vicente, Monte CP. 15, Mindelo, Cape Verde \\ ${ }^{2}$ Physics Department, Instituto Superior Técnico, Av. Rovisco Pais, 1049-001 Lisbon, Portugal
}

Correspondence to: B. Faria (brunofaria@sapo.cv)

Received: 30 July 2013 - Published in Nat. Hazards Earth Syst. Sci. Discuss.: 25 September 2013

Revised: 18 January 2014 - Accepted: 22 January 2014 - Published: 28 February 2014

\begin{abstract}
We describe a new geophysical network deployed in the Cape Verde Archipelago for the assessment and monitoring of volcanic hazards as well as the first results from the network. Across the archipelago, the ages of volcanic activity range from ca. $20 \mathrm{Ma}$ to present. In general, older islands are in the east and younger ones are in the west, but there is no clear age progression of eruptive activity as widely separated islands have erupted contemporaneously on geological timescales. The overall magmatic rate is low, and there are indications that eruptive activity is episodic, with intervals between episodes of intense activity ranging from 1 to $4 \mathrm{Ma}$. Although only Fogo Island has experienced eruptions (mainly effusive) in the historic period (last $550 \mathrm{yr}$ ), Brava and Santo Antão have experienced numerous geologically recent eruptions, including violent explosive eruptions, and show felt seismic activity and geothermal activity. Evidence for recent volcanism in the other islands is more limited and the emphasis has therefore been on monitoring of the three critical islands of Fogo, Brava and Santo Antão, where volcanic hazard levels are highest. Geophysical monitoring of all three islands is now in operation. The first results show that on Fogo, the seismic activity is dominated by hydrothermal events and volcano-tectonic events that may be related to settling of the edifice after the 1995 eruption; in Brava by volcano-tectonic events (mostly offshore), and in Santo Antão by volcano-tectonic events, medium-frequency events and harmonic tremor. Both in Brava and in Santo Antão, the recorded seismicity indicates that relatively shallow magmatic systems are present and causing deformation of the edifices that may include episodes of dike intrusion.
\end{abstract}

1 Introduction: the distribution of volcanic activity in Cape Verde over geological time

The Cape Verde Archipelago consists of 10 major islands - 9 of which are inhabited - and several small islets. Located in the NW Atlantic, about $500 \mathrm{~km}$ off the coast of Senegal (Fig. 1), the islands are volcanic and form a broadly horseshoe-shaped array which opens towards the west and containing two diverging chains with older islands in the east and younger islands in the northwest and southwest. It sits over a ca. $2 \mathrm{~km}$ bathymetric swell of about $1000 \mathrm{~km}$ in diameter which is correlated with other anomalies in seafloor heat flow (Courtney and White, 1986), gravity (Ali and Watts, 2003; Pim et al., 2008) and the geoid (Monnereau and Cazenave, 1990). It has therefore been inferred that the magmatism is due to a hotspot. However, it is not clear whether the root of the plume that sustains the hotspot is deep-seated (Montelli et al., 2006; Pim et al., 2008; Doucelane et al., 2003; Vinnik et al., 2012) or is in the upper mantle (Helffrich et al., 2010). In contrast to other hotspot oceanic island volcano archipelagoes, in Cape Verde there is no clear age progression of the eruptive activity with geographic location as widely separated have islands erupted simultaneously on the geological timescale (Plesner et al., 2002). The geological and geochronological evidence also shows that volcanic activity on the islands tends to be intermittent, with long periods of quiescence (up to a few million years) separating eruptive phases (Holm et al., 2005; Holm et al., 2006; Duprat et al., 2007).

In the historic period since the first settlement around AD 1460, and perhaps for some thousand of years prior, eruptions have occurred only on Fogo Island. However, fresh 

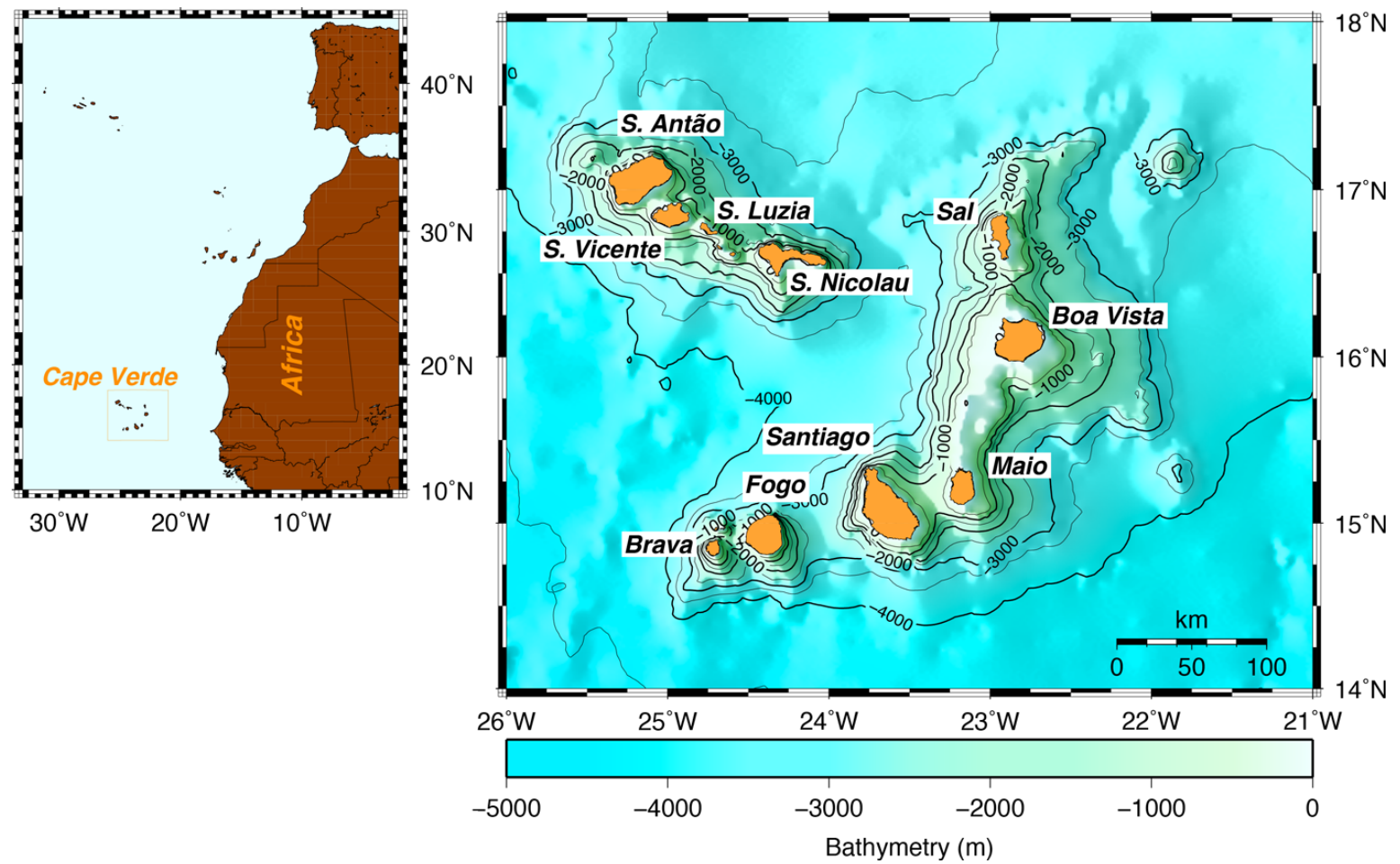

Fig. 1. (Left) Location of the archipelago, North Atlantic. (Right) Geographic distribution of the islands and bathymetry of the archipelago (contour interval $500 \mathrm{~m}$ ).

volcanic vents, lavas and pyroclastic deposits indicate geologically recent activity on other islands, and signs of geological unrest such as island uplift occur in many parts of the archipelago (Ramalho, 2010; Ramalho et al., 2011). Brava and Santo Antão islands display major sequences of morphologically fresh and geologically recent volcanic rocks, including evidences of infrequent but sometimes violently explosive eruptions (Plesner et al., 2002; Mortensen et al., 2009; Tarff and Day, 2013; Day, 2009; Madeira et al., 2010) and important seismicity. In view of these features, it is difficult to exclude a priori the possibility of a reawakening of the activity in any of the islands, but the probability of such an event is likely to be much lower in the eastern islands - where the main sequences of volcanic rocks are deeply eroded and more recent volcanic events are infrequent and small in volume - than in the western islands.

The National Institute for Meteorology and Geophysics (INMG) recently deployed a seismic and geodetic network for the assessment and mitigation of volcanic hazard, with special emphasis on real-time monitoring on Fogo, Brava and Santo Antão. Fifteen seismic stations are currently in operation, covering five islands - Santo Antão, S. Vicente, Sal, Fogo and Brava. In this paper we review the structures of the volcanoes and what is known about volcanic hazards in the Cape Verde islands, describe the new monitoring network, and present some of the data already recorded, with a preliminary discussion of the implications for volcanic hazard.

\section{Geological setting and main volcanic hazards of Fogo Brava and Santo Antão}

\subsection{Fogo Island}

Located in the SW of the Cape Verde Archipelago (Fig. 1), Fogo Island is an active stratovolcano, rising over $6 \mathrm{~km}$ from the $4000 \mathrm{~m}$ deep seafloor to the Pico do Fogo summit at $2829 \mathrm{~m}$ above sea level (m a.s.l.). With an area of $471 \mathrm{~km}^{2}$, Fogo has a population of $\sim 37000$ inhabitants. With mean diameter of $30 \mathrm{~km}$ at a roughly circular base, the island has a nearly conical shape truncated at $\sim 2000 \mathrm{~m}$ a.s.l. by a $9 \mathrm{~km}$ wide lateral collapse scar (Day et al., 1999) opened to the east (Fig. 2). Partial infilling of the collapse scar has produced a nearly horizontal flat plateau known as Chã das Caldeiras, enclosed on the north, west and south by the collapse scar cliff - the Bordeira - which reaches $1000 \mathrm{~m}$ above the plain. A population of about 700 farmers lives in Chã das Caldeiras, and 11000 live on the eastern coast, unprotected by the Bordeira cliff. On the eastern side of Chã das Caldeiras rises the summit cone, Pico do Fogo (Fig. 2). In addition to onshore evidence for the lateral collapse (Day et al., 1999), Masson et al. (2008) reported results of a multibeam bathymetric survey to the east of Fogo, which were interpreted as the avalanche debris of the lateral collapse. Foeken et al. (2009) dated precollapse and post-collapse flows at 123 and $62 \mathrm{Ma}$, respectively, providing a time window for the lateral collapse. 

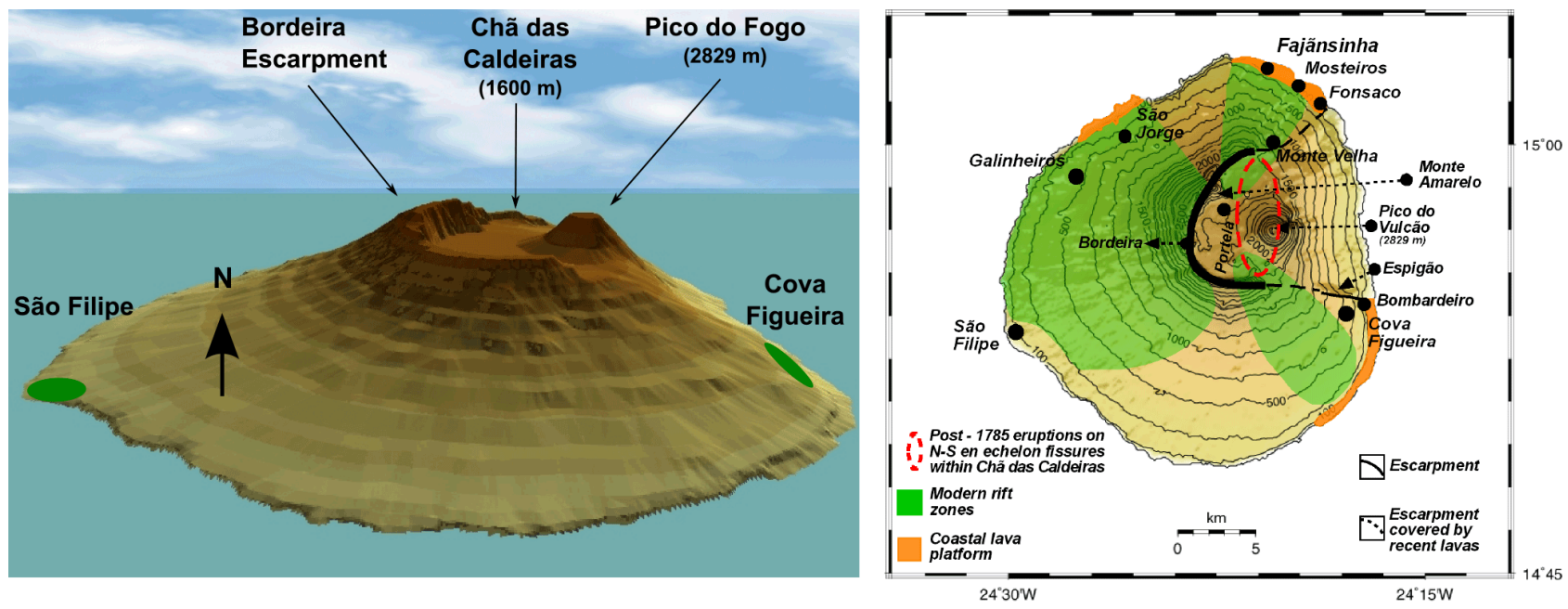

Fig. 2. Main geomorphological and structural features of Fogo. (Left) Perspective view from the south. (Right) Topographic map of Fogo (SRTM model), also showing the modern rift zones; contour lines are in metres. Adapted from Day et al. (1999) and Fonseca et al. (2003).

The flanks of Fogo outside the lateral collapse scar display numerous volcanic vents, concentrated in radial zones which, according to Day et al. (1999), form a modified triplearm rift geometry. The distribution of dikes in the Bordeira cliff replicates these preferential directions: NNE, SSE and a broader sector towards the west. Activity in the southwest of the island ceased about $11 \mathrm{ka}$ ago (Foeken et al., 2009), but eruptions in the east of the island have continued, especially within the collapse scar. Since settlement in the 15th century, 27 eruptions have been identified through analysis of incomplete written records (Ribeiro, 1960), with average time intervals of $20 \mathrm{yr}$ and average duration of two months. According to Ribeiro (1960), until 1725 most historic (i.e. post-dating 1500) eruptions occurred through the Pico do Fogo summit, although more recent mapping (S. Day, personal communication, 2013) indicates that some of these also involved eruptions on flank fissures in the northwest and southeast. In contrast, from the 1785 eruption and to present, the summit of Pico do Fogo has been inactive. The six subsequent eruptions that occurred inside the collapse scar, mainly through $\mathrm{N}-\mathrm{S}$ trending fissures, are arranged in a pattern that suggests that the feeding dikes follow the trends of the NNE and SSE rift zones at greater depths. The exception is the most recent eruption, in 1995, which was fed by the western rift zone (Day et al., 1999; Heleno, 2001; Amelung and Day, 2002). The composition of erupted rocks varied through time, but the most common are ankaramites, nephelinites, basanites, tephrites and scarce phonolitic rocks (Foeken et al., 2009; Hildner et al., 2011; Hildner et al., 2012). The eruptions were mostly effusive (Hawaiian to Strombolian), with rare occurrences of highly explosive episodes including phreatomagmatic events (Day et al., 1999; Foeken et al., 2009).

Ash, lapilli, bombs and lava flows are the most frequent volcanic products on Fogo Island (Torres et al., 1997), and the most significant hazard is associated with lava flows (Ribeiro, 1960; Torres et al., 1997), especially inside the collapse scar and on the very steep eastern coast, which hosts $\sim 30 \%$ of the island's population. In 1951 a village was totally destroyed by lava flows on the eastern coast, and in 1995 another small village was destroyed by lava flows, this time inside Chã das Caldeiras. The 1995 lava flows also covered an economically important agricultural area with some of the best soils of the island. In view of the high speeds that the flow can reach on the steep slopes (Day and Faria, 2009), lava flow hazard can be regarded as high in the caldera floor and very high in the eastern coast.

\subsection{Brava}

Brava, located to the west of Fogo and separated from it by an $18 \mathrm{~km}$ wide channel, is the smallest inhabited island of the archipelago, with an area of $62.5 \mathrm{~km}^{2}$ and a population of $\sim 6000$ inhabitants. It has a broadly circular shape and steep coastal slopes cut by deep erosional valleys. The island has a central summit plateau, where it reaches the maximum amplitude of $976 \mathrm{~m}$ a.s.l. at the peak of Fontainhas (Fig. 4). Day (2009) proposed that this plateau was produced by the infilling with pyroclastic rocks of a wide central collapse caldera $(7 \mathrm{~km} \times 5 \mathrm{~km})$ formed during a catastrophic explosive eruption. Phreatomagmatic craters are widespread in the summit plateau, perhaps due to interaction of rising magmas with a major aquifer in the postulated caldera fill sequence (Day, 2009). Some phonolitic lava domes are also found, both on the plateau and on the outer flanks of the island (Machado, 1968; Madeira et al., 2010; Day, 2009), as are rare subaerial carbonatite lavas and pyroclastic deposits (Madeira et al., 2010).

Rock dating (Hoernle et al., 2002; Madeira et al., 2010) and the juvenile aspect of several craters (Day, 2009; Mourão 


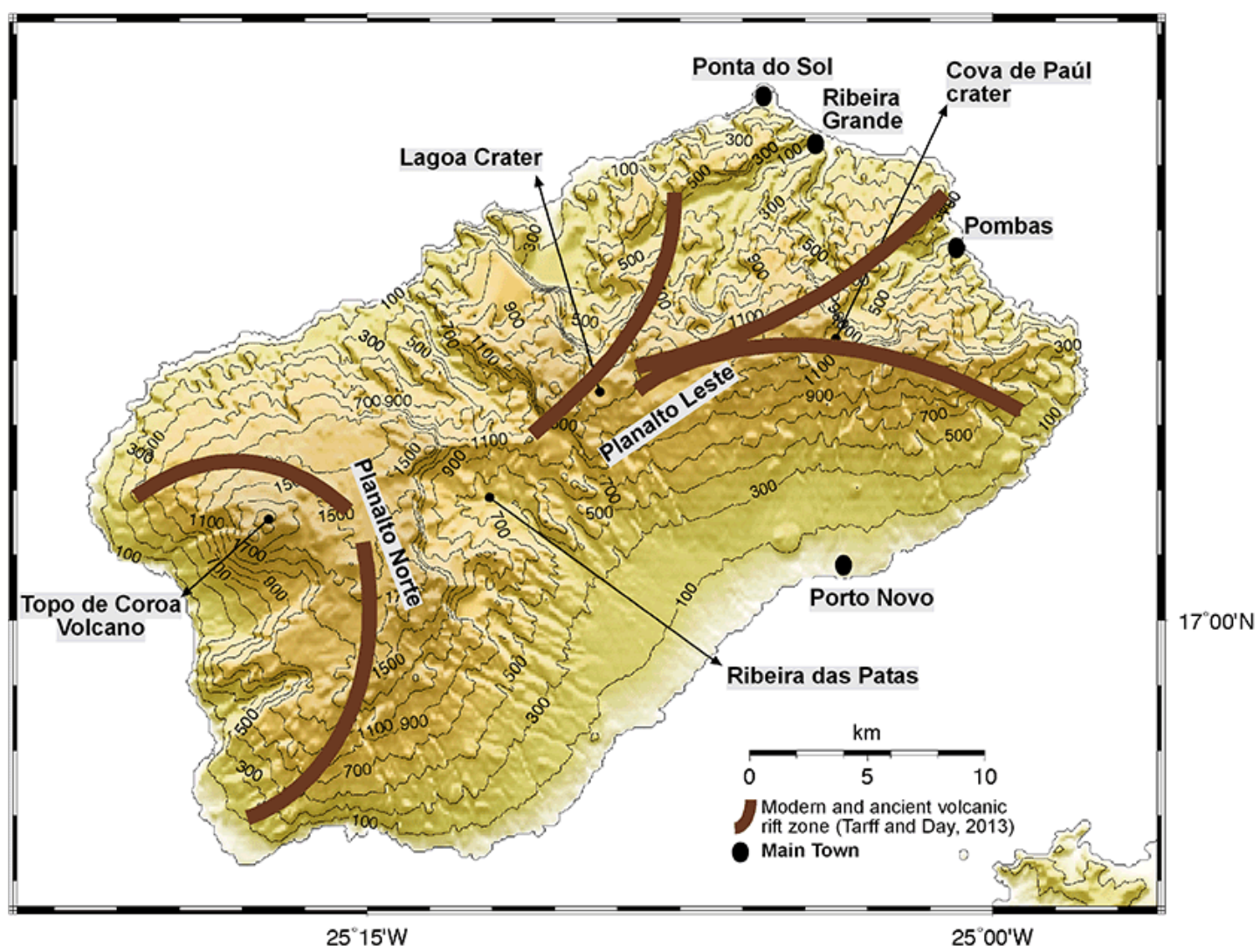

Fig. 3. Topographic map (STRM model) and the main morphologic features of Santo Antão; contour lines are in metres. The locations of the volcanic rift zones are adapted from Tarff and Day (2013).

et al., 2010; Madeira et al., 2010) suggest that the most recent eruptive activity of Brava is Holocene in age. Volcanic hazards are mainly associated with phreatomagmatic eruptions, surge and pyroclastic deposits, and to a lesser extent with lava flows (Machado et al., 1968; Day, 2009; Madeira et al., 2010). The geologically recent volcanic activity appears to have been very explosive, and phreatomagmatic craters are distributed densely on the central plateau, where $82 \%$ of the population lives. Since there have been no historic eruptions in Brava, volcanic hazard awareness among the population and the authorities is very low.

\subsection{Santo Antão}

Santo Antão, located in the northwest of the archipelago and with an area of $784 \mathrm{~km}^{2}$, is the second largest island of Cape Verde, with a population of about 44000 inhabitants spread widely across the island. The economy is based on cattle raising and agriculture, which account for $35 \%$ of the total food production in Cape Verde. It is shaped roughly like a triangular prism, whose arcuate crest - at the mean altitude of $1400 \mathrm{~m}$ a.s.l., but rising to $1800 \mathrm{~m}$ in places - is formed by two plateaus (Fig. 3). One, the Planalto Leste, makes up the central part of the island, and the other, the Planalto Norte in the southwestern end of the island, hosts numerous scoria cones and the highest peak of the island, the stratovolcano Topo de Coroa (1982 ma.s.1.). The slopes of the island are made of thick lava flows covered by sediments and pyroclastics rocks, and have been deeply dissected by erosion that has formed deep canyons, valleys and basins (Tarff and Day, 2013, their supplementary file 1; Plesner et al., 2002; Holm et al., 2006).

Plesner et al. (2002) established the first timeline for the evolution of the island, and the results suggest that the older rocks are at least $7.5 \mathrm{Ma}$ old. After a hiatus of $4.3 \mathrm{Ma}$ the eruptive activity resumed at a lower eruption rate, and the last eruption occurred about $90 \mathrm{ka}$ ago. Based on rock distribution, age and geochemistry, Holm et al. (2006) divided the evolution of Santo Antão into three main phases: from 7.5 to $2 \mathrm{Ma}$, composed mainly of basanite and phonolite rocks; from 2 to $0.3 \mathrm{Ma}$, composed mostly of basanite-phonolite, but also some incidence of nephelinite-phonolite; and from 0.4 to $0.1 \mathrm{Ma}$, composed mainly of nephelinite-phonolite rocks. Tarff and Day (2013) inferred the existence of three overlapping volcanic centres - Ribeira das Patas, Cova de Paúl and Topo de Coroa - and proposed that Ribeira das Patas centre is the oldest, and largely extinct, whilst the other two are younger and both still active. Correlation of the 
distributions of rocks of these three centres with the dated rock location of Plesner et al. (2002) suggest that the activities of these three volcanic centres overlapped in time.

Ribeira das Patas volcano, which is roughly in the centre of the island (Fig. 3), is presently a basin produced by the erosion of hydrothermally altered lavas, opened to the south, about $6 \mathrm{~km}$ in diameter and bounded by an arcuate cliff 900 to $1000 \mathrm{~m}$ high (Tarff and Day, 2013; Plesner et al., 2002). The ages of Ribeira das Patas volcano lava flows range from 7.5 to $1.1 \mathrm{Ma}$ (Plesner at al., 2002). A particular feature of this volcano is a post-erosional scoria cone that formed inside the basin and whose lava is $0.22 \mathrm{Ma}$ old, meaning that the eruption occurred about $1 \mathrm{Ma}$ after the last eruption of Ribeira das Patas volcano and after it had been completely eroded. This feature highlights the intermittent eruptive activity in this island, with long periods of quiescence.

Cova de Paúl volcano, which forms most of the eastern half of Santo Antão, produced thick lava flows that overlap Ribeiras das Patas sequences (possibly infilling an eastfacing collapse scar; Tarff and Day, 2013) and are now eroded by valleys up to $500 \mathrm{~m}$ deep. Tarff and Day (2013) argue that the activity of this volcano occurred along three rift zones, with WSW, NE and SE directions, respectively, extending radially from a summit area with many phonolite domes (Fig. 3). A prominent feature of this volcano is a $300 \mathrm{~m}$ deep crater at the western end of the summit area with a diameter of $1 \mathrm{~km}$ caused by a violent phreatomagmatic explosive eruption that produced pyroclastic flow and surge deposits (Tarff and Day, 2013). Plesner et al. (2002) give an age of $1.35 \mathrm{Ma}$ for the oldest dated lava in this volcano, and $90 \mathrm{ka}$ to the youngest flows.

The volcanic centre of Topo de Coroa constitutes $20 \%$ of the surface of the island towards its SW end (Fig. 3). It consists of numerous young fresh to very fresh scoria cones (i.e. youthful cones of unweathered scoria), phonolitic lava domes and spines. This volcanic centre features a stratovolcano, also called Topo de Coroa (1982 m a.s.l.). According to Tarff and Day (2013) much of the activity of this volcano occurred along two rift zones both running from the east end of the Planalto Norte to the northwest and to the southwest, respectively. The Planalto Norte plateau was built by the infilling with young volcanic rocks of two escarpments opened to the southwest, which Tarff and Day (2013) attribute to two successive lateral collapses. Masson et al. (2008) used multibeam and acoustic backscatter images to map areas of blocky bathymetry offshore of the island, which they interpreted as two different submarine debris avalanche deposits originating from Topo de Coroa. Airfall pumice deposits of phonolitic composition are found almost everywhere on the island, but are especially thick (up to $8 \mathrm{~m}$ ) on the Planalto Norte. The vents of at least two pumice explosions were inferred to belong to the Topo de Coroa volcanic centre (Mortensen et al., 2009; Tarff and Day, 2013), which according to Plesner et al., (2002) was active for about $3 \mathrm{Ma}$, from 3.24 to $0.17 \mathrm{Ma}$.
The potential volcanic hazards in Santo Antão are associated with lava flows, scoria lapilli, pumice airfalls, pyroclastic flows and phreatomagmatic ash and surge deposits. Lahars cannot be ruled out, since flash floods are very common in the deeply incised valleys where non-volcanic but perhaps earthquake-triggered rockfalls and rock avalanches also occur. Earthquakes are felt very often, mainly near the Topo de Coroa volcano, where they frequently reach intensity IV (MMI), but also in the northeast of the island in Cova de Paúl volcano. Thermal waters are common in Santo Antão, with reservoir temperatures reaching $78^{\circ} \mathrm{C}$ and high $\mathrm{CO}_{2}$ concentration, up to $100 \mathrm{mg} \mathrm{L}^{-1}$ (Costa et al., 2001). Together with the seismicity, this geothermal activity indicates that the magmatic systems of the volcanic centres may still be active.

\section{The network}

The network is composed of 15 seismic stations distributed over the islands of Santo Antão, S. Vicente, Sal, Fogo and Brava. It can be subdivided into the Fogo-Brava and Santo Antão sub-networks. The additional stations in Sal and São Vicente islands help constrain locations of more distant earthquakes, while providing limited monitoring of local events. All stations are equipped with analogue threecomponent broadband seismometers (Guralp CMG-3ESPC, with flat response between 0.0166 and $50 \mathrm{~Hz}$ ) and $24 \mathrm{bit}$ analogue-to-digital converters (CMG-DM24). The data are sampled continuously at 50 samples per second per component, and transmitted in real time to INMG in Mindelo (São Vicente Island). Three tilt stations, equipped with Applied Geomechanics AGI-701-2A instruments, were installed in November 2012 on Fogo Island. The data recorded by the tilt stations are also received at INMG in real time (see Fonseca et al., 2013, for the details on the strategy adopted for the telemetry of Fogo and Brava data).

The data received at INMG office in São Vicente are handled by a Guralp CMG-NAM computer and stored on a network-attached storage (NAS) with 2 TB capacity. Automatic RSAM calculation (Endo and Murray, 1991) is in place, and some algorithms based on time-frequency domain analysis to both auto-detect and classify volcanic seismic events are being tested. More detailed analyses, including volcanic event classification, source location and spectral analysis, are performed with the SEISAN package (Ottemöller et al., 2012) and Matlab.

So far, a warning system has been established only for Fogo, which is based on the five levels alert table developed by Faria (2010). In the case of any anomaly, a warning is transmitted to the National Civil Protection Service, which has the responsibility of risk management for Cape Verde. As far as the others islands are concerned, the main goal of the network is to study the local seismicity, investigate whether there is any magmatic process, and then, if necessary, establish warning systems. 


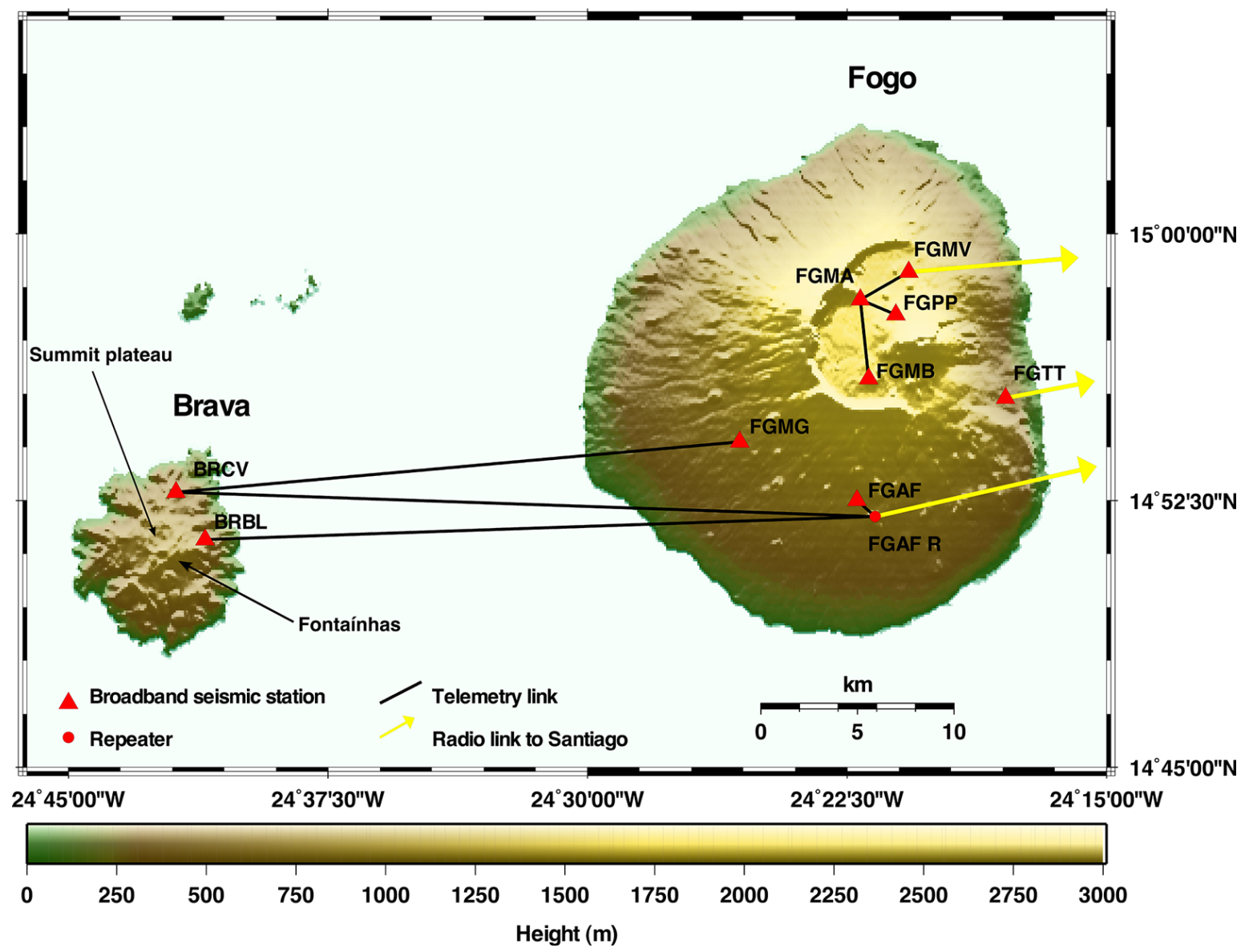

Fig. 4. Geographic location of seismic stations of Fogo and Brava sub-network. The tilt stations are installed at FGMB, FGPP and FGTT.

\subsection{Fogo and Brava sub-network}

This sub-network, deployed in April 2011, consists of seven seismic stations installed on Fogo Island and two on Brava Island (Fig. 4). The Brava stations have the double role of monitoring the seismicity of the island while providing distal recordings of the deeper seismicity underneath Fogo. Conversely, the Fogo stations are important for determining the locations of the seismic activity both onshore and offshore of Brava.

The geometry of Fogo sub-network was designed on the basis of the inference that hypocentres of earthquakes produced by the propagation of dikes feeding future eruptions will most likely be in or near one of the three rift zones. We fixed the location of the hypocentres on the rift zones and used a grid search to place the seismic stations in geographical locations that minimize the time residual misfit. Furthermore we placed at least one station on each rift zone to better constrain the focal depth computation. Whenever possible, the stations were installed in lava tubes at least $3 \mathrm{~m}$ below the surface (FGPP, FGTT and FGAF), or otherwise in vaults dug between 1.5 and $2 \mathrm{~m}$ deep into hard rock. To take advantage of the telemetry, of the analogue to digital converters (CMG-DM-24) and of the vaults infrastructures, the tilt stations were installed in the seismic stations beside the seismometers of the stations FGTT, FGMB and FGPP (Fig. 4). At the time of the writing (May 2013) the tilt signals were characterized only by oscillations of an amplitude smaller than $10 \mu \mathrm{rad}$ and of a period of about $24 \mathrm{~h}$. These signals are likely the response to the deformation produced by the thermo-elastic effect (e.g. Berger, 1975, Bonaccorso, 1999) induced by the diurnal temperature variation.

The locations of Brava seismic stations were chosen taking into account previous seismicity results from temporary networks (Heleno, 2001; Helffrich et al., 2006; Faria, 2010; Grevemeyer et al., 2010), the local geology and the requirement of line of sight to the radio repeaters installed on Fogo (see Fonseca et al., 2013).

\subsection{Santo Antão sub-network}

This sub-network, deployed in July 2010, consists of four stations (Fig. 5). Its geometry resulted mainly from the information obtained by questioning of the population, between 2000 and 2002, about felt earthquakes. This revealed the existence of intense seismic activity in the southwest and in the 


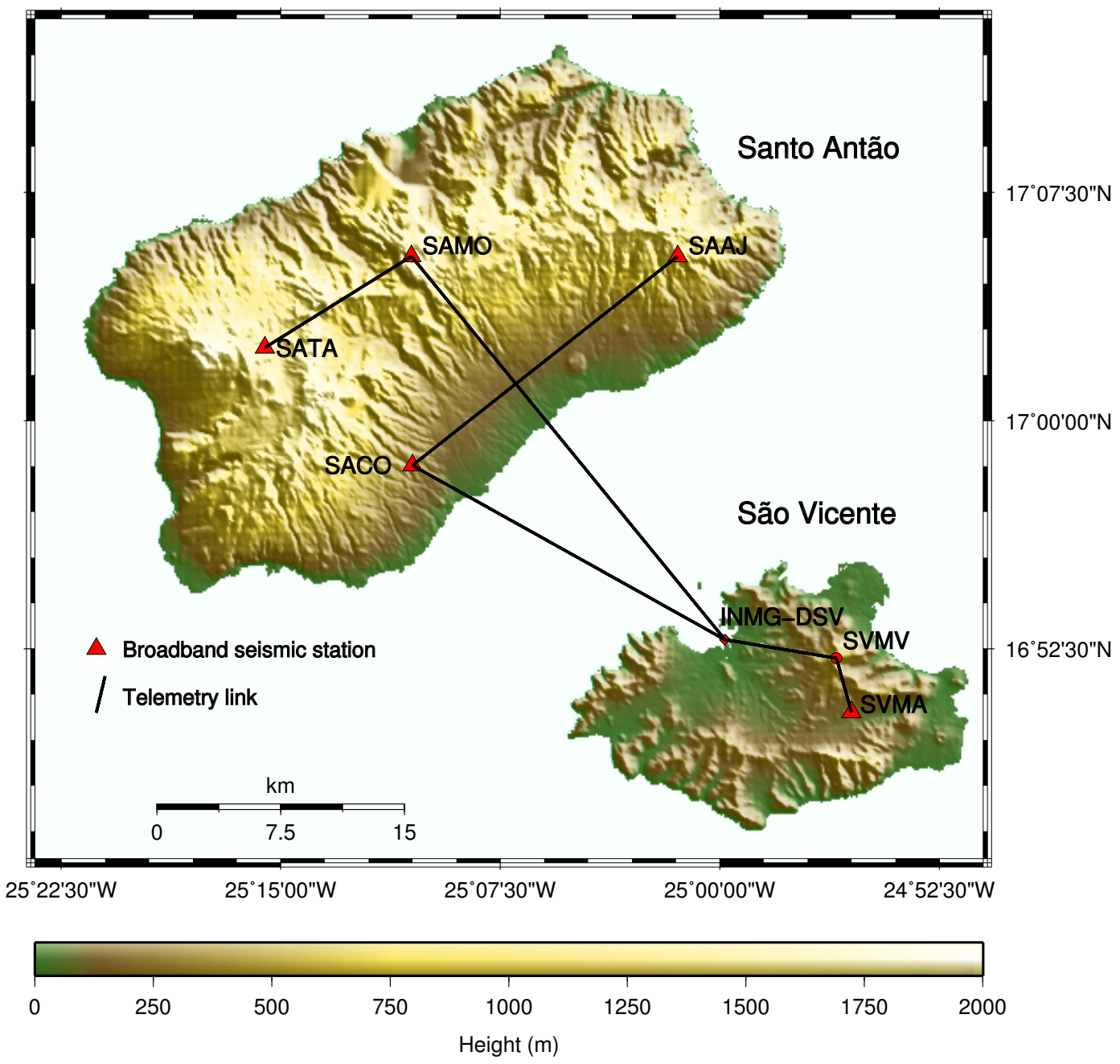

Fig. 5. The seismic sub-network of Santo Antão and its telemetry. Also shown is the location of the station of São Vicente - SVMA. INMG-DSV stands for the INMG laboratory in São Vicente.

northeast, perhaps associated, respectively with the Topo de Coroa and Cova de Paúl volcanoes. The station vaults were dug $1.5 \mathrm{~m}$ deep into hard rock.

Line-of-sight requirements for data transmission were also a constraint in the network geometry. Data are transmitted using two RS-232 links (Fig. 5), each one consisting of three spread spectrum radios (FreeWave FGR115RC): one in the acquisition lab, configured as master; one in the station/repeater (SACO and SAMO) configured as slave/repeater, which transmits data of two stations; and finally one configured as slave at the stations (SAAJ, SATA) that are not in line of sight of the main laboratory in São Vicente (Fig. 5).

\subsection{Sal and São Vicente}

These two islands have a single seismic station each. The seismic station of Sal is installed in a $2 \mathrm{~m}$ deep well dug in a thick limestone layer in the middle of the island (Fig. 1). The data are recorded by an embedded computer in the station, which broadcasts the data using an ADSL internet connection to a gateway on Santiago Island (see Fonseca et al., this issue). In São Vicente, the seismic station is installed almost in the middle of the island (Fig. 5), on the slope of a hill over $\mathrm{a} \sim 1 \mathrm{~m}$ thick basaltic dike. The data are telemetered using a RS-232 link, similar to those used in Santo Antão. This station has a particular relevance to the local seismic activity of Santo Antão as it provides key constraints on the locations of the larger recorded earthquakes.

\section{First results and discussion}

No seismic activity has been recorded to date from beneath the islands of Sal and São Vicente, so this discussion will focus on the activity in and near Fogo, Brava and Santo Antão. 

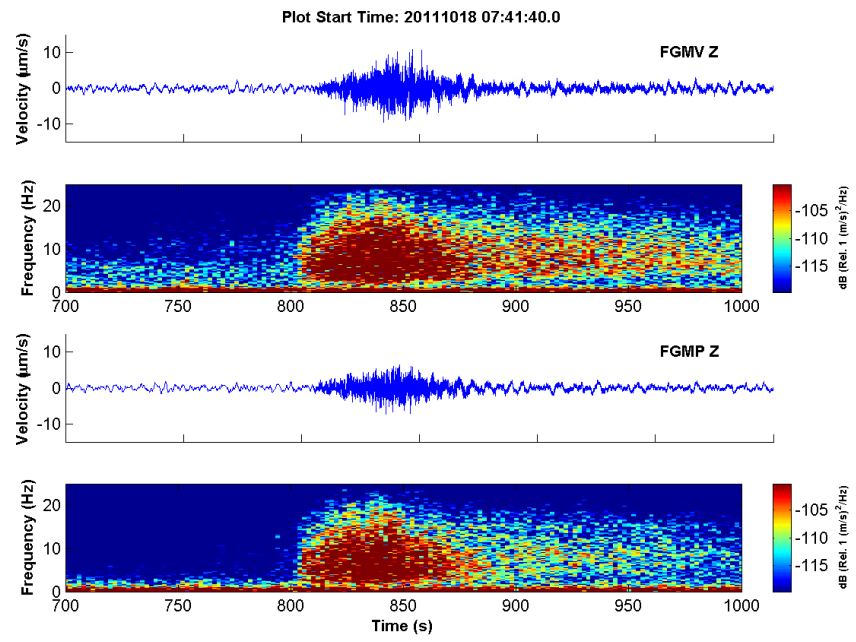

Fig. 6. Example of a cigar-shaped event recorded on Fogo on 18 October 2011 at 07:30 UTC. Seismogram and spectrogram of the vertical component of the stations FGMV (top) and FGPP (bottom). The spectrograms were computed by means of the Welch method using windows of $10.24 \mathrm{~s}$, with $50 \%$ overlap and tapered by a Hanning window also of the same size.

\subsection{Fogo}

A variety of different classes of volcanic seismic events are recorded on Fogo. The most frequent are cigar-shaped (Fig. 6), hybrid, long-period, volcano-tectonic events and spasmodic tremors (Fig. 7). The cigar-shaped events are very emergent; their waveform is, as their name indicates, cigarshaped, with a duration of about $70 \mathrm{~s}$; and the spectra peaks between 5 and $15 \mathrm{~Hz}$. The hybrid events are characterized by apparent impulsive $P$ waves and generally with a lack of $S$ wave, its spectra peaks between 0 and $5 \mathrm{~Hz}$, but with some energy up to $15 \mathrm{~Hz}$ and with a duration of about $1 \mathrm{~min}$. The spasmodic tremor episodes, as with the other types of volcanic tremors, are always very emergent, last from $5 \mathrm{~min}$ to several hours, and their spectra are similar to that of the hybrids or cigar-shaped events. The long-period events recorded on Fogo are very similar to those described by Chouet (1996).

Since the deployment of the Fogo Island stations (April 2011), the seismic rate of cigar-shaped, hybrid and long-period events and spasmodic tremors has shown a seasonal variation. It increases between September and November, the rainy season, and then decreases to the background level (Fig. 8), which is on average about eight events per day. This is similar to the pattern previously reported by Faria (2010) for data recorded on Fogo between 2001 and 2003. These events are characterized by a lack of clear phases, and as a result it is not possible to locate them by means of classical methods. To overcome this difficulty, the wavelet transforms (Vandergheynst et al., 2001) of the recorded seismograms were used to determine $P$-wave ar-
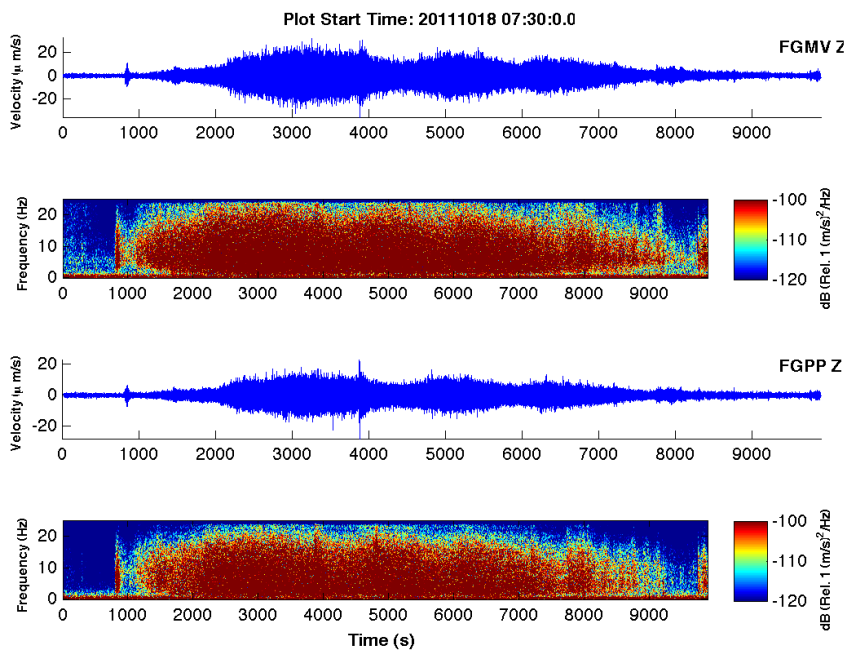

Fig. 7. Example of a spasmodic tremor episode, which lasted for about $2 \mathrm{~h}$, recorded a few minutes after the cigar-shaped event of the Fig. 6. As with the the previous figure, the seismograms and spectrograms are of the vertical component of the stations FGMV (top) and FGPP (bottom). The spectrograms were computed with the same method as the Fig. 6.

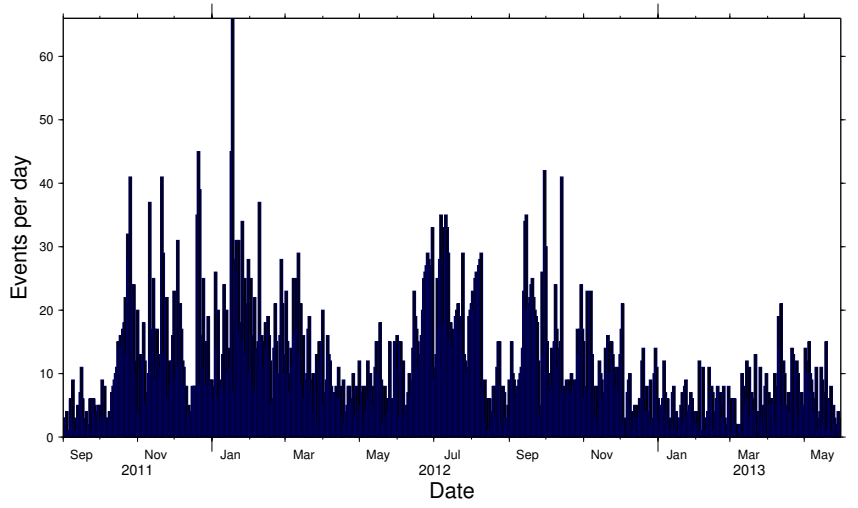

Fig. 8. Evolution of the daily rate of hybrid, cigar-shaped and longperiod events recorded on Fogo between September 2011 and May 2013.

rival time, and by means of a grid search, an approximate location of their source could be found. These locations are mostly below the crater of the 1995 eruption at focal depths ranging from 300 to $400 \mathrm{~m}$ below the surface of Chã das Caldeiras. Faria (2010) hypothesized that this seismicity, including the long-period events, is produced by the hydrothermal activity resulting from percolation of rainwater down to hot rocks in and around the conduit that fed the 1995 eruption. More recently (May 2012), a borehole was drilled in Chã das Caldeiras and the water table was found at $370 \mathrm{~m}$ (A. Silva, personal communication, 2013), reinforcing the hydrothermal hypothesis. We assume therefore that the cigar-shaped, hybrid and long-period events, as well as the spasmodic tremors, are being produced by the hydrothermal 


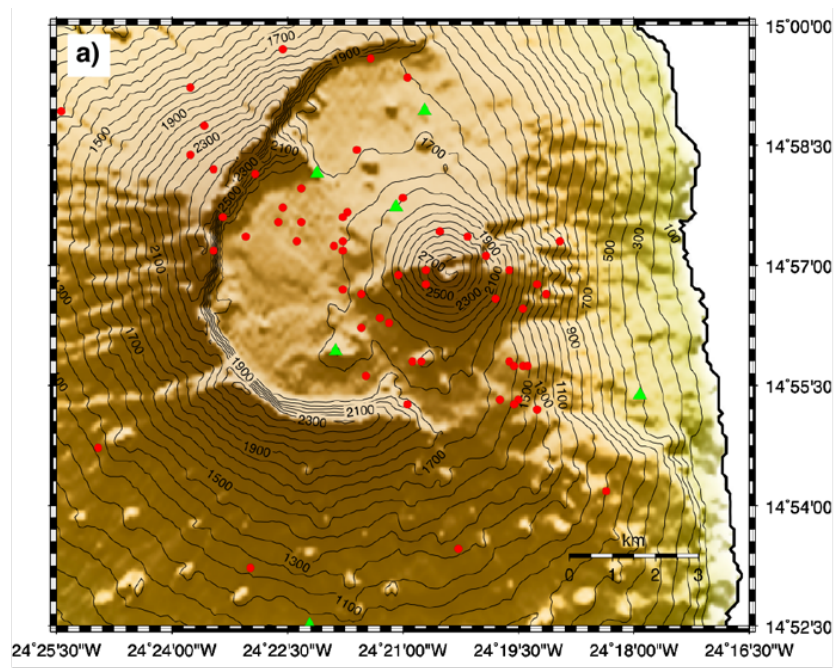

b)

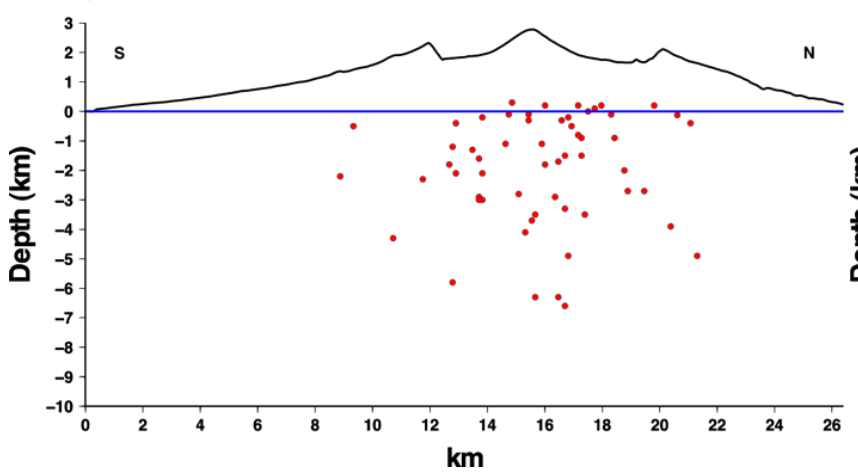

c)

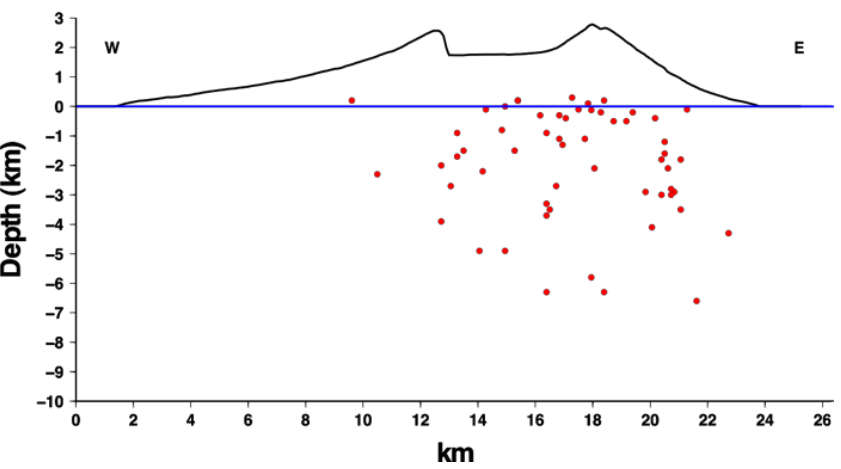

Fig. 9. (a) Epicentral geographic distribution (red dots) of the volcano-tectonic events recorded on Fogo between September 2011 and May 2013 (contour lines are in metres a.s.l., and green triangles represent the seismic stations). (c) Hypocentres projected on a section parallel to the S-N direction. (d) Hypocentres projected on a section parallel to the W-E direction.

processes. These classes of events account for about $98 \%$ of the total activity recorded on Fogo so far.

A total of 57 volcano-tectonic events were recorded on Fogo, with local magnitude ranging between 0.1 and 3.5. The epicentres are located mostly inside Chã das Caldeiras (Fig. 9), with focal depths between 7 and $0 \mathrm{~km}$ (relative to the sea level), but most frequently near sea level.

In most volcanoes, the sources of the volcano-tectonic events are attributed to structural response of the volcanic edifice to the stress produced by magmatic processes (Chouet, 1996). Such processes may include the contraction due to the thermal cooling of a magmatic body, which produces tensile failure of the rocks (Chouet, 1996); dike injection which produces a stress that superposes to the existent ambient stress field (e.g. Rubin and Gillard, 1998); the inflation of the magmatic reservoir, which increases stress, producing rock failure or reactivating pre-existing faults (e.g. Feigl et al., 2000) and gravitational loading of the volcanic edifice (Moran et al., 2000). Dike emplacement as the source of the volcanotectonic events recorded to date on Fogo is ruled out because, for example, the rate is very low (only one event every two months), much below the normal rate in dike-related processes (e.g. McNutt, 1996). In addition, no low-frequency volcanic tremors or long-period events are observed days before or after these events. It is unlikely that they were produced by the inflation of a magmatic reservoir, since the volcano-tectonic earthquakes are at least several kilometres shallower than the shallowest magma reservoirs of the Fogo volcano, which from petrological studies are most probably at more than $13 \mathrm{~km}$ depth (Hildner et al., 2011; Hildner et al., 2012). The hypocentral distribution, the magnitude and the rate of the volcano-tectonic events recorded between 2011 and 2013 maintain the same pattern as found by Faria (2010) for data recorded between 2001 and 2003. This author interpreted the volcano-tectonic earthquakes from that time interval as being due to the long-term gravitational readjustment of the collapse scar fill to inflation of the whole island produced by the 1995 eruption, which produces shearing failure between fossil dikes and unconsolidated material at the collapse scar. This is also consistent with the structural 


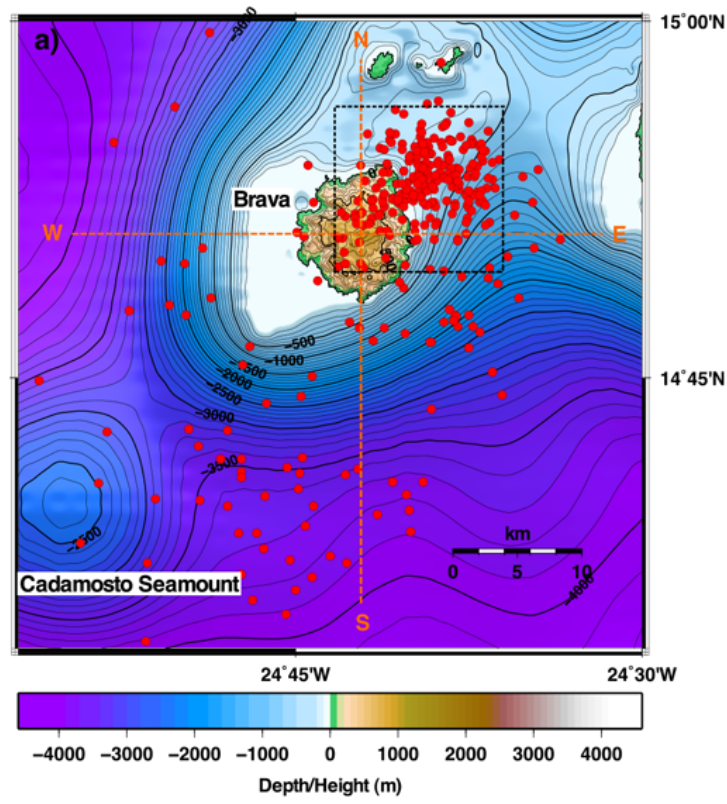

c)

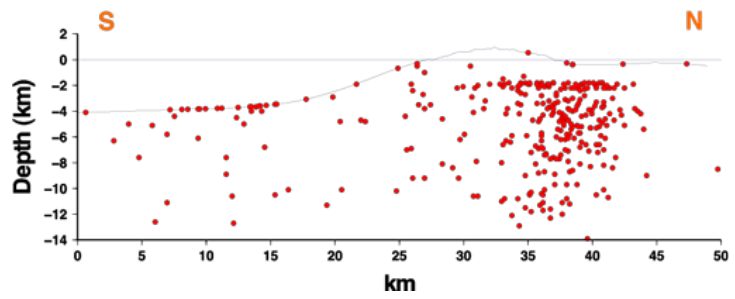

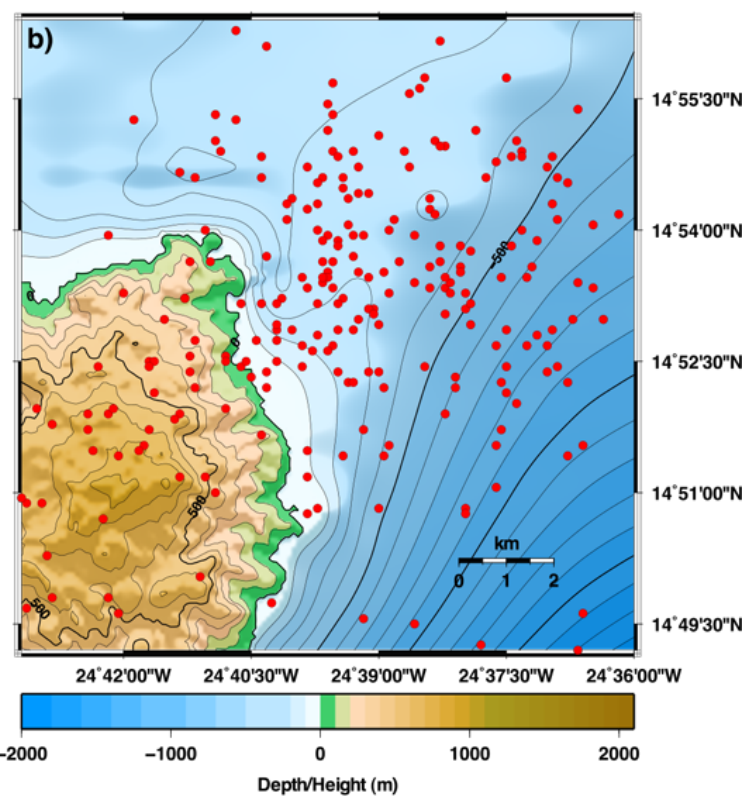

d)

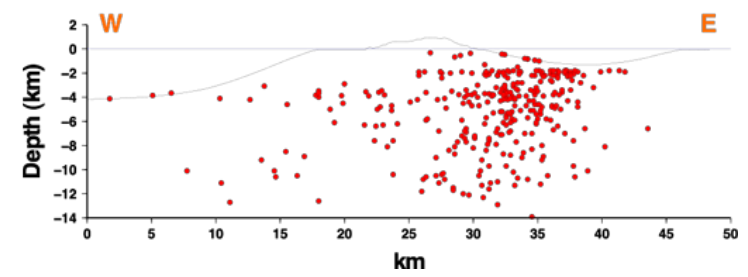

Fig. 10. (a) Epicentral geographic distribution (red dots) of the seismic events recorded in or near Brava between September 2011 and May 2013, as well as the bathymetry (contour interval $100 \mathrm{~m}$ ). (b) A detailed view of seismic events around the NE of Brava (inset box from a). (c) Hypocentres projected on a section parallel to the S-N direction. (d) Hypocentres projected on a section parallel to the W-E direction.

reconstruction of Fogo by Day et al. (1999), who proposed that the basal surface of the collapse scar was lined with an unconsolidated debris layer, approximately at sea level. We therefore attribute the volcano-tectonic events recorded since 2011 to the same mechanism of shearing at the base of the collapse scar.

\subsection{Brava}

The seismic activity recorded in Brava is dominated by volcano-tectonic events. The mean seismic rate is one event per day, but with a wide variation reflecting the occurrence of seismic swarms (in strong contrast to the situation on Fogo, discussed above). These swarms consist generally of at least three to four events recorded on a time period of less than an hour. One such swarm (March 2012) reached a peak of more than 40 events recorded on a single day.

The volcano-tectonic events have a local magnitude between 0.7 and 3.2, and most have epicentres offshore (Fig. 10). A strong concentration of epicentres can be seen to the NE of the island, in an area where Masson et al. (2008) and Grevemeyer et al. (2010) reported submarine volcanic
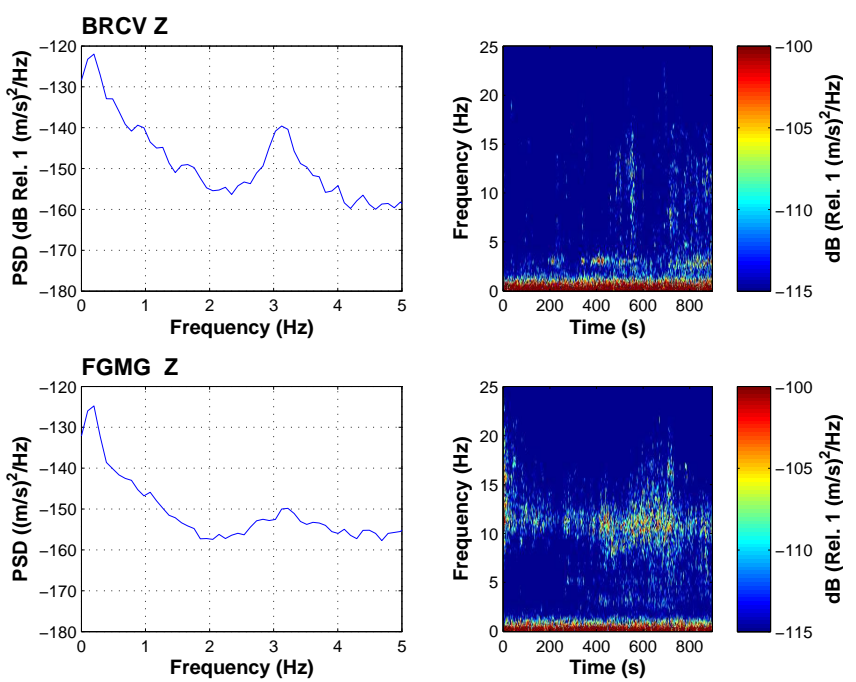

Fig. 11. Spectrogram (right), computed as in Fig. 6, of 15 min windows of the vertical component of ground velocity for a harmonic tremor episode recorded on 8 March 2012 at 08:00 UTC by BRCV (top) and FGMG (bottom) seismic stations as well as a detailed view of the power spectra (left) between 0 and $5 \mathrm{~Hz}$. 


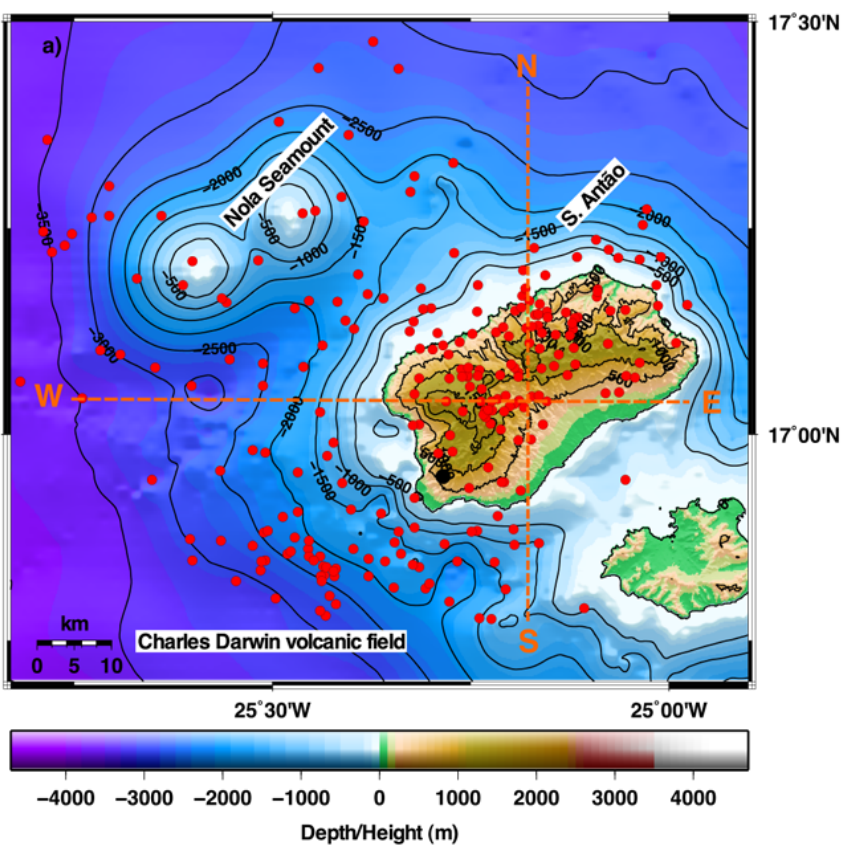

b)

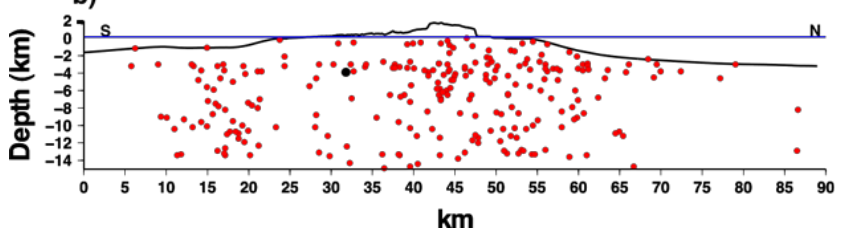

c)

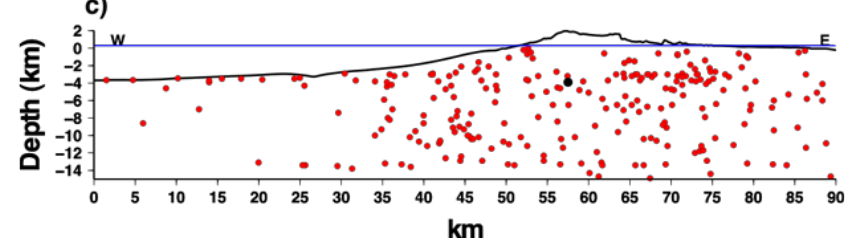

Fig. 12. Epicentral geographic distribution (red dots) of the seismic events recorded in or near S. Antão between August 2010 and May 2013, and the bathymetry (contour interval $100 \mathrm{~m}$ ). (b) Hypocentres projected on a section parallel to the $\mathrm{S}-\mathrm{N}$ direction. (c) Hypocentres projected on a section parallel to the W-E direction. The black dot represents the location (on the SW rift zone) of the first event recorded during the seismic swarm (Fig. 14) that occurred on 13 December 2011.

cones. A second, more scattered, concentration of epicentres can be seen to the SE of the island, where Hansteen et al. (2013) sampled fresh volcanic products and proposed a recent submarine eruption.

The March 2012 seismic swarm was located in the NE cluster and coincided with the occurrence of harmonic tremor episodes. The beginning of the swarm (at about 08:00 UTC on 8 March) was marked by an episode of low-frequency $(\sim 3 \mathrm{~Hz}$ ) harmonic tremor (Fig. 11), which lasted for about $15 \mathrm{~min}$. This episode of tremor was recorded by the westernmost station on Fogo (FGMG) and, more intensely, by the northernmost station in Brava (BRCV). It is thus plausible that the source of this tremor was also located near or at the NE cluster. Generally, low-frequency $(<5 \mathrm{~Hz})$ harmonic tremors are attributed to processes related to magma movement (e.g. McNutt, 1996; Chouet, 1996). It is likely that the swarm and harmonic tremor episodes were produced by magma intrusion underneath a submarine volcano. This hypothesis is reinforced by the previous occurrence of several high-frequency $(>5 \mathrm{~Hz}$ ) harmonic tremor episodes recorded on Fogo and Brava between 1999 and 2002, which were in- terpreted as related to submarine volcanic processes (Heleno et al., 2006).

Taking into account that subaerial older submarine volcanic and intrusive sequences are found up to $300 \mathrm{~m}$ above the present sea level, Day (2009), Madeira et al. (2010) and Ramalho (2011) proposed that Brava is experiencing sustained uplift, which may be caused by crustal magmatic intrusions in the form of sills or laccoliths. It is possible that some of the volcano-tectonic events with focal depths between 2 and $10 \mathrm{~km}$ are produced by these processes as suggested by the Fig. 10, particularly c and d.

\subsection{Santo Antão}

During the first three years of operation of the network on Santo Antão the seismic activity observed consists mainly of volcano-tectonic events, medium-frequency events and harmonic volcanic tremor episodes. The local magnitudes range from 0.1 to 4.5 . The mean rate is three events per day, but as is the case with Brava, the rate varies widely, mainly due to frequent seismic swarms. 

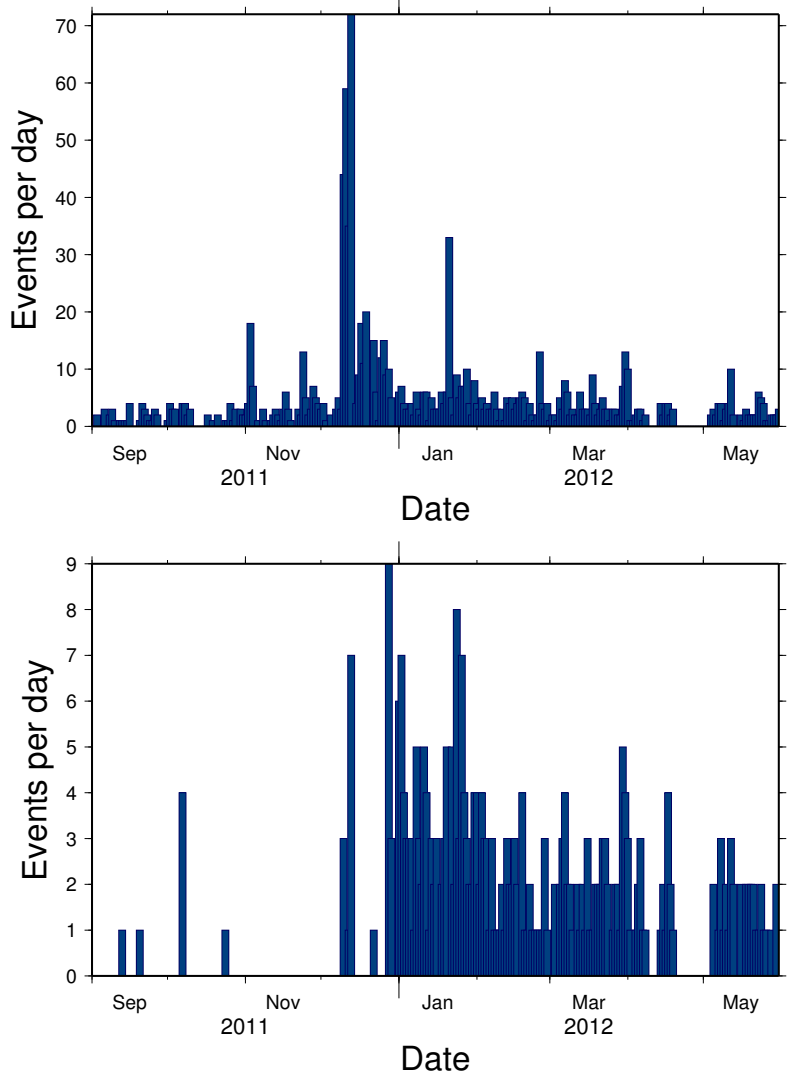

Fig. 13. Evolution of the seismic activity rate of Santo Antão for volcano-tectonic events (a) and for medium-frequency events (b).

The epicentres (Fig. 12) show a diffuse pattern, covering most of the island and extending offshore to the NW and SW. Despite the diffuseness of the picture defined by the offshore epicentres, Fig. 12 indicates that they are grouped in two main zones: one to the NW and the other to the SW of Santo Antão. The NW group is geographically correlated with Nola Seamount, and the SW group with the Charles Darwin volcanic field, which was discovered recently (Masson et al., 2008). More recently, both Nola Seamount and the Charles Darwin volcanic field were investigated in detail by means of multibeam sonar bathymetric mapping and dredging (Hansteen et al., 2013). The Charles Darwin volcanic field consists of a myriad of volcanic cones at more than $3000 \mathrm{~m}$ deep. Nola Seamount comprises two submarine peaks separated by a plateau at about $100 \mathrm{~m}$ deep. Young volcanic products were dredged from both, but no evidence of Holocene volcanic activity was found on these submarine volcanic structures (Hansteen et al., 2013). However, the occurrence of frequent seismic swarms may indicate that the activity is associated with intrusive processes.

An important feature of the seismic activity onshore Santo Antão, with focal depths between 3 and $13 \mathrm{~km}$, is the frequent occurrence of swarms. A prominent swarm happened on December 2011, which lasted for the whole month (Fig. 13a),
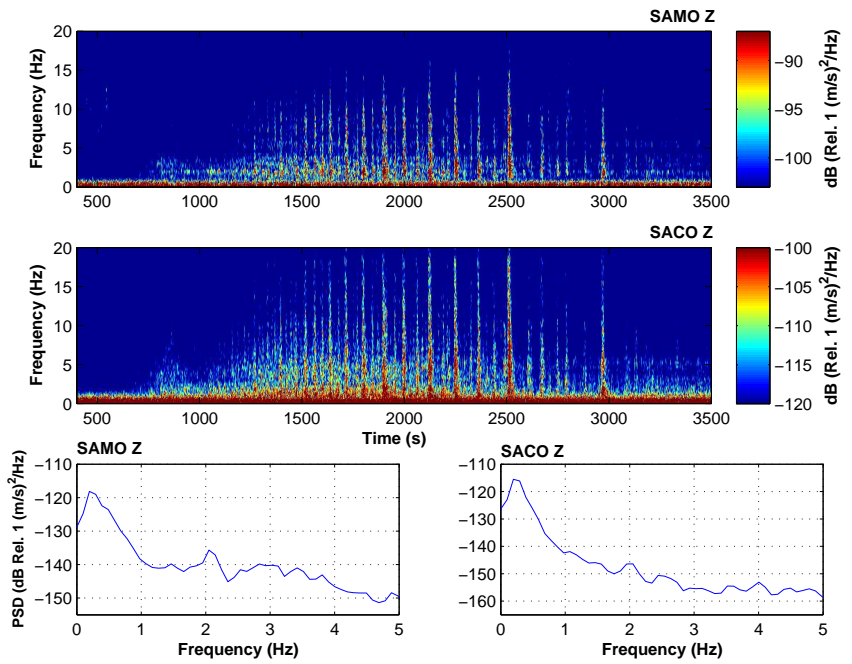

Fig. 14. Spectrogram (top) of $1 \mathrm{~h}$ windows of vertical component of SAMO and SACO seismic stations of ground velocity of the seismic swarm recorded on 13 December 2011 between 18:40 and 20:00 UTC, and a detailed view between 0 and $5 \mathrm{~Hz}$ of the power spectra (bottom) of $10 \mathrm{~min}$ time window before the swarm, which display a peak around $2 \mathrm{~Hz}$. The spectrograms were computed with the same method as Fig. 6.

and reached a peak of more than 70 volcano-tectonic events in one day. Between 18:40 and 20:00 (UTC) on 13 December, more than 30 events (Fig. 14) were observed. It was only possible to locate the first of these, which was on the SW rift zone of the Topo de Coroa volcano (Fig. 12). All the stations recorded a low-frequency $(\sim 2 \mathrm{~Hz})$ harmonic volcanic tremor episode (Fig. 14), beginning about $10 \mathrm{~min}$ before the start of this swarm and lasting for at least $10 \mathrm{~min}$. Towards the end of this seismic swarm, the medium-frequency event rate increased and reached a local maximum at the end of December 2011, when it decreased exponentially back to the background level (Fig. 13b).

The sequence of (1) low-frequency $(<5 \mathrm{~Hz})$ volcanic tremor episodes, (2) volcano-tectonic events located on the volcanic rift zones and finally (3) medium-frequency events suggests that the seismic activity recorded during the December 2011-January 2012 episode in Santo Antão may have been associated with magmatic intrusion in the SW rift zone of Topo de Coroa.

\section{Conclusions}

The distribution of seismic activity recorded by the Cape Verde Geophysical Network in its first few years of operation is consistent with previous geological studies that indicate that whilst infrequent volcanic activity may occur anywhere in the archipelago and may show long-term cyclicity, volcanic activity and volcanic hazards are presently concentrated in the western islands of Fogo, Brava and Santo 

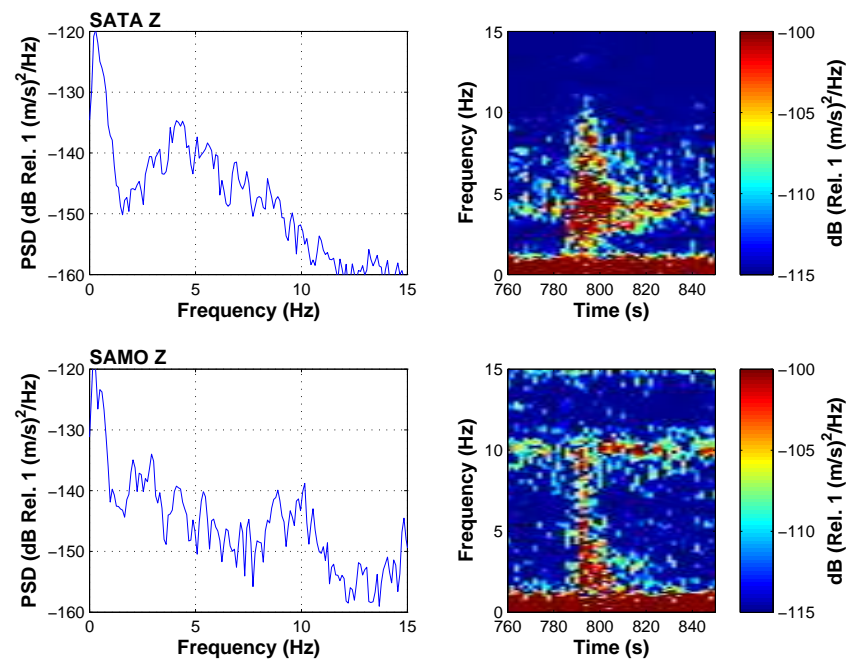

Fig. 15. Spectrogram (left), computed as in Fig. 6, of vertical component of ground velocity of a medium-frequency event recorded on 1 January 2012 at 00:12 UTC by SATA (top) and SAMO (bottom) and a detailed view between 0 and $5 \mathrm{~Hz}$ of the power spectra (right) of the signal.

Antão. In addition to significant numbers of events under these islands, offshore seismic activity probably related to submarine seamounts and volcanic fields was also recorded, indicating that these structures may be still active or are frequently subject to magmatic intrusions.

Amongst the three western islands, Fogo displays the highest seismic rate, but it is dominated by seasonally varying very shallow hydrothermal activity and by persistently low levels of volcano-tectonic earthquake activity, not associated with seismic swarms, that are linked to structural readjustments following the recent 1995 eruption. The seismic activity onshore and nearshore of Brava and Santo Antão does occur in discrete swarms and is probably associated with magmatic intrusions either within the deeper parts of the edifices or in underlying oceanic crust. This raises the possibility of eruptions on these islands in the near future. However, quantification of the probability of such eruptions as well as the assessment of the hazards that may result requires further investigation. Continued and extended monitoring, geophysical surveys of the subsurface structures of the volcanoes, and, most importantly, detailed geological mapping and absolute age dating of the younger volcanic sequences, are required to establish the frequencies of occurrence of different types of volcanic activity on the different islands and hence the probabilities of occurrence of different volcanic hazards.
Acknowledgements. Fogo seismic stations and telemetry were funded partially by the MIA-VITA project under Work Packages 3 and 6. The MIA-VITA project was financed by the European Commission under the 7th Framework Programme for Research and Technological Development, Area "Environment", Activity 6.1 "Climate Change, Pollution and Risks". INMG acknowledges CVTELECOM for hosting the repeaters in its facilities (Monte Tchota and Achada Furna) and for providing technical support for the data transmission. Garantia (insurance) funded the solar panels of the stations of Santo Antão. The municipalities of Santo Antão have partially funded the network of that island. VIVO Energy (Shell, Cape Verde) is also acknowledged for the permanent availability for transporting our equipment to Fogo. The support of Ministry of Agriculture office in Santo Antão, particularly of Mr. Orlando Freitas, was crucial for the deployment of the seismic stations in Santo Antão. The authors are grateful to S. Day for his careful review of the manuscript, comments and suggestions, as well as the provision of geological information for Brava, which was fundamental for the seismic stations site selection there. The authors would also like to thank two anonymous reviewers, the editor, P. Jousset and R. Ramalho, whose comments and suggestions improved the quality of this paper.

Edited by: P. Jousset

Reviewed by: three anonymous referees

\section{References}

Ali, M. Y. and Watts, A. B.: A seismic reflection profile study of the lithospheric flexure in the vicinity of the Cape Verde Islands, J. Geophys. Res., 108, 2239, doi10.1029/2002JB002155, 2003.

Amelung, F. and Day, S.: InSar observation of the 1995 Fogo, Cape Verde, eruption: Implication for the effects of collapse events upon island volcanoes, Geophys. Res. Lett., 29, 47-1-474, doi:10.1029/2001GL013760, 2002.

Berger, J.: A note on Thermoelastic strain and tilts, J. Geophys. Res., 80, 274-277, 1975.

Bonaccorso, A., Falzone, G., and Gambino, S.: An investigation into shallow borehole tiltmeters, Geophys. Res. Lett., 26, 16371640, 1999.

Chouet, B. A.: New Methods and future trends in seismological volcano monitoring, in: Monitoring and mitigation of volcano hazards, edited by: Scarpa, R. and Tilling, R., Springer-Verlag, Berlin, 1996.

Costa, A., Atalaya, S., Reis, P., Pires, S., Monteiro, C., Fonseca, J., Alves, L., Miranda, V., and Graça Carvalho, M.: Análise do mercado energético e potencial de penetração de tecnologias europeias de energias renováveis em Cabo Verde, Relatório final, THERMIE type B action No STR/1938/98/PT, 2001.

Courtney, R. C. and White, R. S.: Anomalous heat flow and geoid across the Cape Verde Rise: evidence for dynamic support from a thermal plume in the mantle, Geophys. J. Astr. Soc., 87, 815867, 1986.

Day, S. J.: Field Excursion to Brava, 24-25 June, MIA-VITA Workshop, São Filipe, Fogo, 2009.

Day, S. and Faria, B.: A geological hazard map of the Island of Fogo showing broad distribution of volcanic and other hazards, MIA-VITA Workshop, São Filipe, Fogo, 2009. 
Day, S. J., Heleno da Silva, S. I. N., and Fonseca, J. F. B. D.: A past giant lateral collapse and present-day flank instability of Fogo, Cape Verde Islands, J. Volcanol. Geotherm. Res., 94, 191-218, 1999.

Doucelance, R., Escrig, S., Moreira, M., Gariépy, C., and Kurz, M.: $\mathrm{Pb}-\mathrm{Sr}-\mathrm{He}$ isotope and trace element geochemistry of the Cape Verde Archipelago, Geochim. Cosmochim. Acta, 67, 37173733, 2003.

Duprat, H. I., Friis, J., Holm, P. M., Grandvuinet, T., and Sørensen, R. V.: The volcanic and geochemical development of São Nicolau, Cape Verde Islands: constraints from field and ${ }^{40} \mathrm{Ar} /{ }^{39} \mathrm{Ar}$ evidence, J. Volcanol. Geotherm. Res., 162, 1-19, 2007.

Endo, E. T. and Murray, T.: Real-time Seismic Amplitude Measurement (RSAM): a volcano monitoring and prediction tool, Bull. Volcanol., 53, 533-545, 1991.

Faria, B.: Monitorização Geofísica do Vulcão do Fogo e Níveis de Alerta, Ph.D thesis, Universidade Técnica de Lisboa, 2010 (in Portuguese).

Feigl, K., Gasperi, J., Sigmundsson, F., and Rigo, A.: Crustal deformation near Hengill volcano, Iceland 1993-1998: Coupling between magmatic activity and faulting inferred from elastic modeling of satellite radar interferograms, J. Geophys. Res., 105, 25655-25670, 2000.

Foeken, J., Day, S., and Stuart, F.: Cosmogenic ${ }^{3}$ He exposure dating of the Quaternary basalts from Fogo, Cape Verdes: Implications for rift zone and magmatic reorganisation, Quaternary Geochron., 4, 37-49, doi:10.1016/j.quageo.2008.07.002, 2009.

Fonseca J. B. D., Faria, B., Lima, N. P., Heleno, S. I. N., Lazaro, C., d'Oreye, N. F., Ferreira, A. M. G., Barros, I. J. M., Santos, P., Bandomo, Z., Day, S., Osorio, J. P., Baio, M., and Matos, J. L. G.: Multiparameter monitoring of Fogo Island, Cape Verde, for volcanic risk mitigation, J. Volcanol. Geotherm. Res., 125, 39-56, 2003.

Fonseca, J. F. B. D., Faria, B. V. E., Trindade, J., Cruz, G., Chambel, A., Silva, F. M., Pereira, R. L., and Vazão, T.: "Last mile" challenges to in situ volcanic data transmission, Nat. Hazards Earth Syst. Sci., 13, 3419-3428, doi:10.5194/nhess-13-34192013, 2013.

Grevemeyer I., Helffrich, G., Faria, B., Booth-Rea, G., Schnabel, G., and Weinrebe, W.: Seismic activity at Cadamosto seamount near Fogo Island, Cape Verdes - formation of a new ocean island?, Geophys. J. Int., 180, 552-558, 2010.

Hansteen, T. H., Kwasnitschka, T., and Klügel, A. (Eds.): Cape Verde Seamounts - R/V Meteor cruise No. 80 Leg 3, 29 December-1 February 2010, unpublished report, 2013.

Heleno, S. I. N., Estudo Sismológico do Vulcão do Fogo, Ph.D. thesis, Universidade Técnica de Lisboa, 2001 (in Portuguese).

Heleno, S. I. N., Faria, B. V. E., Bandomo, Z., and Fonseca, J. F. B. D.: Observations of high-frequency harmonic tremor in Fogo, Cape Verde Islands, J. Volcanol. Geotherm. Res., 158, 361-379, 2006

Helffrich, G., Heleno, S. I. N., Faria, B., and Fonseca, J. F. B. D.: Hydroacoustic detection of volcanic ocean-island earthquakes, Geophys. J. Int., 167, 1529-1536, 2006.

Helffrich, G., Faria, B., Fonseca, J., Lodge, A., and Kaneshima, S.: Transition zone structure under a stationary hot spot: Cape Verde, Earth Planet. Sci. Lett., 289, 156-161, 2010.
Hildner, H., Klügle, A., and Hauff, F.: Magma storage and ascent during the 1995 eruption of Fogo, Cape Verde Archipelago, Contrib. Mineral Petrol., 162, 751-772, 2011.

Hildner, H., Klügle, A., and Hansteen, T.: Barometry of lavas from 1951 eruption of Fogo, Cape Verde Islands: Implications for historic and prehistoric magma plumbing system, J. Volcanol. Geotherm. Res., 217-218, 73-90, 2012.

Hoernle, K., Tilton, G., Le Bas, M. J., Duggen, S., and GarbeSchönberg, D.: Geochemistry of oceanic carbonatites compared with continental carbonatites: mantle recycling of oceanic crustal carbonate, Contrib. Mineral. Petrol., 142, 520-542, doi:10.1007/s004100100308, 2002.

Holm, P. M., Wilson, J. R., Kokfelt, T. F., Grandvuinet, T., Friis, J., and Plesner, S.: The age distribution of volcanism on the Cape Verde Islands, Sal2005 International Workshop on Ocean Island Volcanism, Ilha do Sal, 2-8 April, 2005.

Holm, P. M., Wilson, J. R., Christensen, B. P., Hansen, L., Hansen, S. L., Hein, K. M., Mortensen, A. K., Pedersen, R., Plesner, S., and Runge, M. K.: Sampling the Cape Verde mantle plume: evolution of melt compositions on Santo Antão, Cape Verde Islands, J. Petrol., 47, 145-189, doi:10.1093/petrology/egi071, 2006.

Machado, F., Leme, J. A., and Monjardino, J. L.: Carta Geológica da Ilha Brava e dos Ilhéus Secos, J. Inv. Ultramar, Lisboa, 1968.

Madeira, J., Mata, J., Mourão, C., Brum da Silveria, A., Martins, S., Ramalho, R., and Hoffmann, D. L.: Volcano-stratigraphic and structural evolution of Brava Island (Cape Verde) based on ${ }^{40} \mathrm{Ar}$ ${ }^{39} \mathrm{Ar}$, U-TH and field constrains, J. Volcanol. Geotherm. Res., 196, 219-235, 2010.

Masson, D. G., Le Bas, T. P., Grevemeyer, I., and Weinrebe, W. Flank collapse and large-scale landsliding in the Cape Verde Islands, off West Africa, Geochem. Geophy. Geosy., 9, Q07015, doi:10.1029/2008GC001983, 2008.

McNutt, S. R.: Seismic Monitoring and Eruption Forecasting of Volcanoes: A Review of the State-of-the-Art and Case Histories, in: Monitoring and Mitigation of Volcanic Hazards, edited by: Scarpa, R. and Tilling, R., Springer-Verlag, Berlin, 1996.

Monnereau, M. and Cazenave, A.: Depth and geoid anomalies over oceanic hotspots swells: A global survey, J. Geophys. Res., 95, 15429-15438, 1990.

Montelli, R., Nolet, G., Dahlen, F. A., and Masters, G.: A catalogue of deep mantle plumes: New results from finitefrequency tomography, Geochem. Geophy. Geosy., 7, Q11007, doi:10.1029/2006GC001248, 2006.

Moran, S. C., Zimbelman, D. R., and Malone, S. D.: A model from the magmatic-hydrothermal system at Mount Rainer, Washington, for seismic and geochemical observations, Bull. Volcanol., $61,425-436,2000$

Mortensen, A. K., Wilson, J. R., and Holm, P. M.: The Cão Grande phonolitic fall deposit on Santo Antão, Cape Verde Islands, J. Volcanol. Geortherm. Res., 179, 120-132, 2009.

Mourão C., Mata, J., Doucelance, R., Madeira, J., Brum da Silveira, A., Silva, L. C., and Moreira, M.: Quaternary extrusive calciocarbonatite volcanism on Brava Island (Cape Verde): A nephelinite-carbonatite immiscibility product, J. African Earth Sci., 56, doi:10.1016/j.jafrearsci.2009.06.003, 59-74, 2010.

Ottemöller L., Voss, P., and Havskov, J. (Eds.): SEISAN: The Earthquakes Analysis Software, Version 9.1, 2012 
Pim, J., Peirce, C., Watts, A. B., Grevemeyer, I., and Krabbenhoeft, A.: Crustal structure and the origin of the Cape Verde Rise, Earth Planet. Sci. Lett., 272, 422-428, 2008.

Plesner, S., Holm, P. M., and Wilson, J. R.: ${ }^{40} \mathrm{Ar}-{ }^{39}$ Ar geochronology of Santo Antão, Cape Verde Islands, J. Volcanol. Geotherm. Res., 120, 103-121, 2002.

Ramalho, R.: Building the Cape Verde Islands, Springer, 1st Edition, 2011.

Ramalho, R., Helffrich, G., Shimdt, D. N., and Vance, D.: Tracers of uplift and subsidence in Cape Verde Archipelago, J. Geol. Soc. London, 167, 519-538, 2010.

Ribeiro, O.: A ilha do Fogo e as suas erupções, $12^{a}$ edição, Memórias, Série Geográfica, J. Inv. Ultramar, 1960.

Rubin, A. M. and Gillard, D.: Dike-Induced earthquakes: Theoretical consideration, J. Geophys. Res., 103, 10017-10030, 1998.
Torres, P. C., Madeira, J., Silva, L. C., Brum da Silveira, A., Serralheiro, A. and Mota Gomes, A.: Carta Geológica das erupções da ilha do Fogo: Revisão e actualização, in: A Erupção Vulcânica de 1995 na Ilha do Fogo, Cabo Verde, edited by: Rafega, A., Figueiredo, M. O., Silva, L. C., Costa, F. L., Mendes, M. H., Torres, P. C., da Silva T. P., and Correia, E., Instituto de Investigação Científica Tropical, Lisboa, 1997.

Tarff, R. W. and Day, S. J.: Chilled margin fragmentation as a trigger for transition from Strombolian to phreatomagmatic explosive activity at Cova de Paul Crater, Santo Antão, Cape Verde Islands, Bull. Volcanol., 75, 735, doi:10.1007/s00445-013-0735$0,2013$.

Vandergheynst, P., Antoine, J.-P., Van Vyve, E., Goldberg, A., and Doghri, I.: Modeling and simulation of an impact test using wavelets, analytical solution and finite elements, Int. J. Sol. Struct., 38, 5481-5508, 2001.

Vinnik, L., Graça Silveira, S., Kiselev, V., Farra, M., Weber, M. and Stutzmann, E.: Cape Verde hotspot from the upper crust to the top of the lower mantle, Earth Planet. Sci. Lett., 319-320, 259-268, 2012. 